\title{
Preparasi Dan Penentuan Energi Gap Film Tipis TiO2:Cu Yang Ditumbuhkan Menggunakan Spin Coating
}

\author{
Vita Efelina \\ Universitas Singaperbangsa Karawang \\ Email : vita.efelina@mail.ugm.ac.id
}

Received February 1, 2017; Revised March 20, 2017; Accepted March 23, 2017

\begin{abstract}
Abstrak
Lapisan tipis $\mathrm{TiO}_{2}$ doping $\mathrm{Cu}$ telah berhasil ditumbuhkan di atas substrat kaca dengan teknik spin coating. Lapisan tipis $\mathrm{TiO}_{2}$ : $\mathrm{Cu}$ dibuat dengan konsentrasi doping 1 hingga 10 wt.\% dengan suhu annealing $500^{\circ} \mathrm{C}$. Hasil analisis spektrum transmitansi pada daerah UV-Vis menunjukkan bahwa lapisan tipis yang ditumbuhkan dengan suhu annealing $500^{\circ} \mathrm{C}$ memiliki energy gap untuk transisi langsung sebesar 3,51-3,59 eV dan untuk transisi tidak langsung sebesar 3,26-3,57 eV. Energy gap paling sempit yang dapat dicapai pada lapisan tipis $\mathrm{TiO}_{2}: \mathrm{Cu}$ dengan suhu annealing $500^{\circ} \mathrm{C}$ adalah pada konsentrasi $\mathrm{Cu} 8 \%$. Penggunaan doping $\mathrm{Cu}$ dapat memperlebar spektrum serapan cahaya dari lapisan tipis $\mathrm{TiO}_{2}$ sehingga lapisan tipis $\mathrm{TiO}_{2}$ : $\mathrm{Cu}$ dapat diaplikasikan sebagai anti pantulan pada sel surya.
\end{abstract}

Kata kunci: $\mathrm{TiO}_{2}, \mathrm{Cu}$, UV Vis, spin coating

Preparation And Study Of Gap Energy TiO $\mathrm{O}_{2}:$ Cu Thin Film Fabricated By Spin Coating Technique

\begin{abstract}
$\mathrm{Cu}$ doped $\mathrm{TiO}_{2}$ thin film have been successfully grown on corning substrates by spin coating technique. Concentration of $\mathrm{Cu}$ doping on $\mathrm{TiO}_{2}$ thin films are in the range 1 to $10 \mathrm{wt}$.\%. Analysis of transmission spectrum from ultra violet to visible energy range show that $\mathrm{TiO}_{2}$ : $\mathrm{Cu}$ thin film grown at annealing temperature of $500^{\circ} \mathrm{C}$ has direct transition energy gap is 3,51-3,59 $\mathrm{eV}$ and indirect transition is 3,26-3,57 eV. The narrowest energy gap $\mathrm{TiO}_{2}$ : $\mathrm{Cu}$ thin films under annealing temperature of $500^{\circ} \mathrm{C}$ yields when the Cu doping concentration is $8 \%$. The value of direct and indirect energy gap of its are respectifely 3,51 eV and 3,26 eV.. The direct and indirect energy gap on this condition are respectively 3,53 $\mathrm{eV}$ and 3,32 $\mathrm{eV}$. Cu doping thin films can widen the range of light absorption spectra of $\mathrm{TiO}_{2}$ so these thin films, can be applied as an anti-reflecting layer on sollar cell.
\end{abstract}

Keywords: $\mathrm{TiO}_{2}, \mathrm{Cu}, \mathrm{UV}$ Vis, spin coating

\section{PENDAHULUAN}

Titanium dioksida $\left(\mathrm{TiO}_{2}\right)$ merupakan bahan yang memiliki konstanta dielektrik tinggi. Salah satu manfaat dari bahan yang memiliki konstanta dielektrik tinggi yaitu dapat mencegah kebocoran arus. $\mathrm{TiO}_{2}$ dapat dijadikan sebagai bahan utama dalam pembuatan alat-alat elektronik dan sensor. $\mathrm{TiO}_{2}$ memiliki stabilitas kimia tinggi dan tidak beracun. Titanium dioksida murni memiliki energi gap yang lebar yaitu sebesar $3,2 \mathrm{eV} . \mathrm{TiO}_{2}$ hanya mampu menyerap cahaya di bawah $400 \mathrm{~nm}$ yaitu pada daerah UV, sehingga untuk memaksimalkan serapan energi matahari khususnya pada spektrum sinar tampak, $\mathrm{TiO}_{2}$ perlu didoping dengan dopan tertentu[Indah, 2009].
Penggunaan doping dilakukan untuk memperkecil energi gap dan memperbesar spektrum serapan cahaya dari Titanium dioksida. Doping yang baik harus dapat meningkatkan tepi atas pita valensi dan memperkecil energi gap. Salah satunya adalah melalui proses doping logam yang dapat memperbesar respon cahaya dari $\mathrm{TiO}_{2}$ terhadap spektrum sinar tampak[Choi, 1994]. Penelitian sebelumnya tentang pengujian film tipis $\mathrm{Ba}_{0,5} \mathrm{Sr}_{0,5}, \mathrm{TiO}_{3}$ sebagai sensor cahaya berbantuan rangkaian elektronika. Penelitian tersebut menggunakan metode chemical solution deposition (CSD)[Farida dkk, 2016]. Beberapa penelitian telah dilakukan salah satunya $\mathrm{TiO}_{2}$ doping $\mathrm{Cu}$ untuk berbagai kandungan $\mathrm{Cu}(\mathrm{Cu}-$ Nitrat, $\mathrm{Cu}-\mathrm{Sulfat}, \mathrm{Cu}$-Asetat dan $\mathrm{Cu}-\mathrm{Klorida})$ 
dengan variasi konsentrasi sebesar 1\%,3\%, dan $5 \%$. Mereka menyatakan dari hasil karakterisasi DRS (Diffuse Reflectance Spectroscopy) dapat menurunkan energi gap dari 3,2 hingga 2,58 eV. Dari berbagai kandungan $\mathrm{Cu}$ yang digunakan tersebut, doping $\mathrm{Cu}-\mathrm{Nitrat}$ dengan variasi konsentrasi $1 \%, 3 \%$ dan $5 \%$ paling efektif menurunkan energi gap berturut-turut sebesar 2,97 eV, 2,83 eV dan 2,58 eV. Cu-Nitrat digunakan dalam penelitian ini sebagai doping karena paling efektif memperkecil energi gap pada $\mathrm{TiO}_{2}$ [Slamet, 2007].

Pembuatan lapisan tipis $\mathrm{TiO}_{2}$ doping $\mathrm{Cu}$ dilakukan dengan teknik spin coating. Spin coating merupakan metode fabrikasi yang dapat digunakan untuk menumbuhkan lapisan tipis dengan kualitas yang baik, mudah dibuat pada suhu kamar dan murah. Namun kualitas film tipis yang ditumbuhkan dengan teknik ini sangat peka terhadap parameter fabrikasi yang digunakan, antara lain pelarut, substrat dan temperatur annealing [Musliahfatun, 2010].

Karakterisasi sifat optik lapisan tipis dilakukan dengan menggunakan spektrometer UV-Vis (Ultra violet-visible). Spektroskopi UVVis dilakukan untuk memperoleh data transmitansi dari $\mathrm{TiO}_{2}: \mathrm{Cu}$ sehingga dapat diketahui energi gapnya melalui perhitungan ketebalan lapisan, indek bias dan koefisien absorbsi. Berdasarkan pemaparan tersebut, maka penelitian yang akan dilakukan adalah pengaruh konsentrasi doping $\mathrm{Cu}$ pada lapisan tipis $\mathrm{TiO}_{2}$ yang ditumbuhkan dengan teknik spin coating terhadap energi gap.

\section{METODE}

\subsection{Tahap Menyiapkan Subtrat, larutan Cu dan} larutan $\mathrm{TiO}_{2}$

Subtrat dibersihkan menggunakan Ethanol, selanjutnya subtrat tersebut dikeringkan menggunakan hotplate selama 5 menit dengan temperatur $100{ }^{\circ} \mathrm{C}$ untuk menghilangkan uap air yang tertinggal. Setelah itu, pembuatan larutan $\mathrm{Cu} \quad(\mathrm{Cu}-\mathrm{Nitrat})$ dengan variasi konsentrasi $1 \%, 2 \%, 3 \%, 4 \%, 5 \%, 6 \%, 7 \%, 8 \%, 9 \%$ dan $10 \%$ menggunkan larutan $\mathrm{HCl}$. Dalam penelitian ini $\mathrm{Cu}$ yang digunakan dalam bentuk padatan yang masing-masing konsentrasi dicampur dengan 0,01 liter $\mathrm{HCl}$. Kemudian pembuatan larutan $\mathrm{TiO}_{2}$ dengan $0,5 \mathrm{M}$. Konsentrasi $0,5 \mathrm{M}$ didapat dari 0,39 gram bubuk $\mathrm{TiO}_{2}$ yang dicampur dengan 0,01 liter aquades. Larutan
$\mathrm{TiO}_{2}$ dan $\mathrm{Cu}$ masing-masing diaduk menggunakan magnetic stirer selama 3 jam dengan laju putaran $700 \mathrm{rpm}$. Setelah larutan $\mathrm{Cu}$ dan $\mathrm{TiO}_{2}$ selesai dibuat, maka kedua larutan tersebut dicampur dengan cara menuangkan larutan $\mathrm{Cu}$ ke dalam larutan $\mathrm{TiO}_{2}$. Campuran larutan diaduk selama 30 menit menggunakan magnetic stirer, kemudian dibiarkan selama 24 jam[Prathama, 2010].

\subsection{Tahap Pembuatan Lapisan Tipis}

Tahap berikutnya adalah pembuatan lapisan tipis, yaitu dengan mengambil 4 tetes larutan $\mathrm{TiO}_{2}: \mathrm{Cu}$ untuk diteteskan pada substrat kaca yang sudah ditempatkan pada alat spin coating. Kemudian substrat yang telah ditetesi larutan $\mathrm{TiO}_{2}: \mathrm{Cu}(1 \%, 2 \%, 3 \%, 4 \%, 5 \%, 6 \%, 7 \%, 8 \%$, $9 \%$ dan $10 \%$ ) diputar dengan tegangan 7,5 volt (kecepatan putar piringan $1371 \mathrm{rpm}$ ) selama 15 detik. Setelah dilakukan proses pemutaran menggunakan spin coating, langkah berikutnya adalah melakukan pemanasan awal (pre annealing) dengan menggunakan hotplate dengan suhu $150{ }^{\circ} \mathrm{C}$ selama 30 menit. Pre annealing berfungsi untuk menghilangkan uap air (pelarut) pada lapisan tipis. Kemudian melakukan pemanasan (annealing) dengan menggunakan furnace dengan variasi suhu 500 ${ }^{\circ} \mathrm{C}$ dan $600{ }^{\circ} \mathrm{C}$ selama 8 jam. Proses annealing berfungsi untuk memperbaiki struktur kristal[Prathama, 2010]. Larutan $\mathrm{TiO}_{2}$ yang di campurkan dengan $\mathrm{H}_{2} \mathrm{O}$ menjadi $\mathrm{TiO}_{2}+\mathrm{H}_{2} \mathrm{O} \rightarrow \mathrm{TiO}_{2} \cdot \mathrm{H}_{2} \mathrm{O}$, sedangkan untuk larutan $\mathrm{Cu}$ nitrat yang ditambahkan dengan $\mathrm{HCl}$ menjadi : $\mathrm{Cu}\left(\mathrm{NO}_{3}\right)_{2}+2 \mathrm{HCl} \rightarrow \mathrm{CuCl}_{2}+2 \mathrm{HNO}_{3}$ [Faith dkk, 1975] . Larutan yang diteteskan di atas substrat adalah larutan $\mathrm{Cu}$-doped $\mathrm{TiO}_{2}$ [Coleman, N, 2015].

\subsection{Tahap Spektroskopi UV-Vis}

Lapisan tipis $\mathrm{TiO}_{2}: \mathrm{Cu}$ diuji menggunakan spektrometer UV-Vis. Pengukuran dengan menggunakan spektrometer UV-Vis diperoleh data dalam bentuk data transmitansi. Data antara panjang gelombang dari cahaya ultraviolet hingga cahaya tampak terhadap transmitansi lapisan tipis $\mathrm{TiO}_{2}$ : $\mathrm{Cu}$. Data-data tersebut dianalisis untuk mengetahui besarnya energi gap pada lapisan tipis $\mathrm{TiO}_{2}$ : $\mathrm{Cu}$. Penentuan energi gap lapisan $\mathrm{TiO}_{2}: \mathrm{Cu}$ dapat ditentukan dengan metode Tauc plot[Tauc, 1966]. Metode Tauc Plot yaitu dengan menarik ekstrapolasi pada 
daerah linier dari grafik hubungan $(h v)$ sebagai

absis dan $(\alpha h v)^{n}$ sebagai ordinat hingga memotong sumbu energi. Perhitungan tersebut menggunakan persamaan $\alpha h v=A(h v-E g)^{n}$. Jika transisi terjadi secara langsung, maka $n=1 / 2$ sehingga persamaan menjadi [Chong, 2006]:

$$
\begin{gathered}
\alpha h v=A(h v-E g)^{1 / 2}, \\
(\alpha h v)^{2}=A^{2}(h v-E g), \\
(\alpha h v)^{2}=A^{2} h v-A^{2} E g,
\end{gathered}
$$

dengan menggunakan persamaan garis

$Y=m x+C$, maka:

$$
\begin{gathered}
0=A^{2} h v-A^{2} E g, \\
0=h v-E g, \\
E g=h v
\end{gathered}
$$

Gambar 1 dibawah ini menggambarkan hubungan antara $h v$ dengan $(\alpha h v)^{2}$ yang digunakan untuk menentukan energi gap.

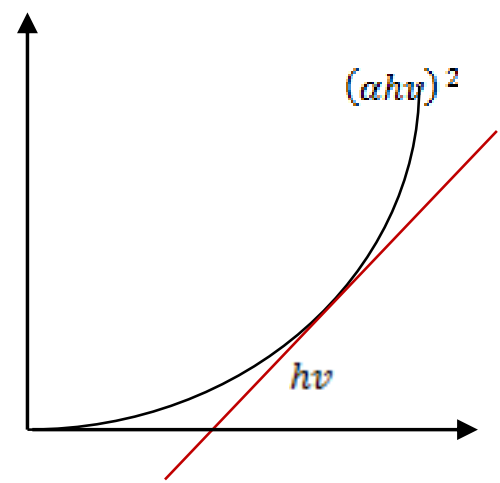

Gambar 1. Penentuan energi gap

Koefisien absorbsi ( $\alpha$ ) merupakan hubungan antara transmitansi sebagai fungsi gelombang dengan ketebalan lapisan tipis yang di ukur [Swanepoel, 1983].

$$
\alpha=-\frac{1}{d} \ln T
$$

(d) Ketebalan lapisan tipis $\mathrm{TiO}_{2}: \mathrm{Cu}$ dapat ditentukan dengan menggunakan metode Swanepoel [Swanepoel, 1983]

$$
d=\frac{\lambda_{1} \lambda_{2}}{2\left(\lambda_{1} n_{2}-\lambda_{2} n_{1}\right)}
$$

dengan $d$ ketebalan lapisan $(\mathrm{nm}), \lambda_{1}$ dan $\lambda_{2}$ adalah panjang gelombang pada masing-masing puncak, $\mathrm{n}_{1}$ dan $\mathrm{n}_{2}$ adalah indeks bias lapisan tipis pada masing-masing panjang gelombang $\lambda_{1}$ dan $\lambda_{2}$.

indeks bias (n) lapisan tipis yang dinyatakan dalam persamaan sebagai berikut [Swanepoel, 1983]

$$
\begin{aligned}
n= & \sqrt{N+\sqrt{N^{2}-n_{s}^{2}}} \\
N= & 2 n_{s} \frac{T_{M-} T_{m}}{T_{M} T_{m}}+\frac{n_{s}^{2}+1}{2} \\
& n_{s} \text { adalah indeks bias substrat kaca }
\end{aligned}
$$

(1.51), $T_{M}$ dan $T_{m}$ masing-masing adalah nilai transmitansi maksimum (\%) dan transmitansi minimum (\%).

\section{HASIL DAN PEMBAHASAN}

3.1 Pembuatan Larutan $\mathrm{TiO}_{2}$ dan $\mathrm{Cu}$

Larutan $\mathrm{TiO}_{2}$ didapatkan dari 0,39 gram bubuk $\mathrm{TiO}_{2}$. Bubuk $\mathrm{TiO}_{2}$ diencerkan menggunakan 0,01 liter aquades, sehingga diperoleh larutan $\mathrm{TiO}_{2}$. Kemudian pembuatan larutan $\mathrm{Cu}(\mathrm{Cu}-$ Nitrat) dengan variasi konsentrasi 1\%, $2 \%, 3 \%$, $4 \%, 5 \%, 6 \%, 7 \%, 8 \%, 9 \%$ dan $10 \%$ menggunakan larutan $\mathrm{HCl}$. $\mathrm{Cu}$ yang digunakan masih dalam bentuk padatan yang masingmasing konsentrasi dicampur dengan 0,01 liter $\mathrm{HCl} . \mathrm{Cu}$ dengan konsentrasi $1 \%$ diperoleh dengan menggunakan persamaan sebagai berikut: 
Jurnal Pendidikan Fisika dan Keilmuan (JPFK) Vol 3 No 1 Maret 2017, hal 19-27

Avaliable online at : http://e-journal.unipma.ac.id/index.php/JPFK

Print ISSN: 2442-8868, Online ISSN: 2442-904x

$$
\begin{aligned}
& 1 \%=\frac{x}{x+\mathrm{TiO}_{2}} \\
& 0,01=\frac{x}{x+0,39} \\
& 0,01(x+0,39)=x \\
& 0,01 x+3,9.10^{-3}=x \\
& x=0,0039 \text { gram }
\end{aligned}
$$

Pembuatan larutan $\mathrm{Cu}$ dengan berbagai konsentrasi $\mathrm{HCl}$ di tunjukkan pada tabel 1. di bawah ini :

Tabel 1 .Pembuatan larutan $\mathrm{Cu}$

\begin{tabular}{cccc}
\hline Larutan & $\begin{array}{c}\text { Konsentrasi } \\
\mathbf{C u} \\
(\boldsymbol{\%})\end{array}$ & $\begin{array}{c}\mathbf{C u} \\
(\mathbf{g})\end{array}$ & $\begin{array}{c}\text { HCl } \\
(\mathbf{m l})\end{array}$ \\
\hline Sampel-1 & 1 & 0,0039 & 10 \\
Sampel-2 & 2 & 0,0080 & 10 \\
Sampel-3 & 3 & 0,0121 & 10 \\
Sampel-4 & 4 & 0,0162 & 10 \\
Sampel-5 & 5 & 0,0205 & 10 \\
Sampel-6 & 6 & 0,0249 & 10 \\
Sampel-7 & 7 & 0,0294 & 10 \\
Sampel-8 & 8 & 0,0339 & 10 \\
Sampel-9 & 9 & 0,0386 & 10 \\
Sampel-10 & 10 & 0,0433 & 10 \\
\hline
\end{tabular}

Larutan $\mathrm{TiO}_{2}$ dan $\mathrm{Cu}$ diaduk menggunakan magnetic stirer selama 3 jam dengan laju putaran $700 \mathrm{rpm}$. Setelah larutan $\mathrm{Cu}$ dan $\mathrm{TiO}_{2}$ selesai dibuat, maka kedua larutan tersebut dicampur dengan cara menuangkan larutan $\mathrm{Cu}$ ke dalam larutan $\mathrm{TiO}_{2}$. Campuran larutan diaduk selama 30 menit menggunakan magnetic stirer, kemudian dibiarkan selama 24 jam.

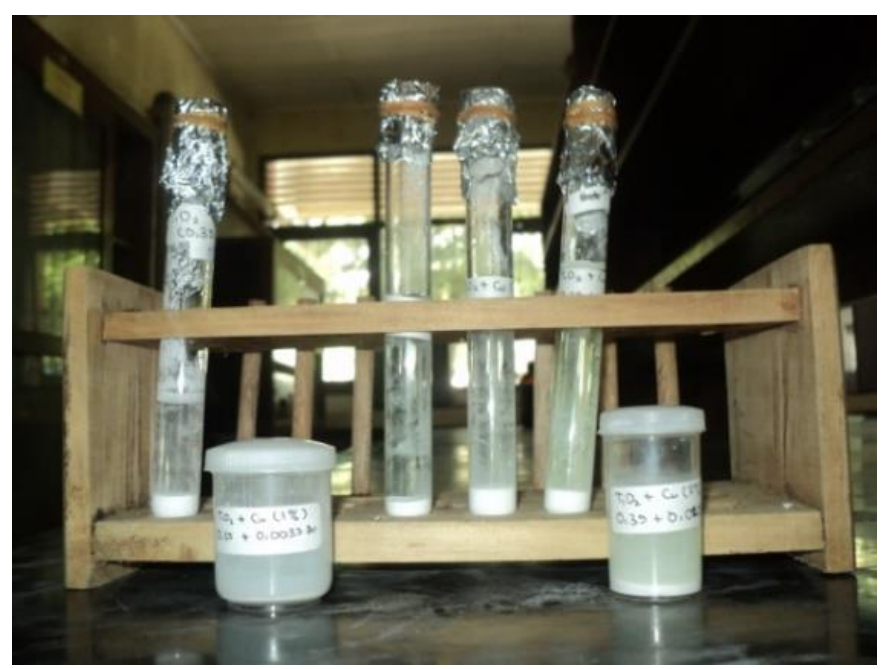

Gambar 2. Larutan $\mathrm{TiO}_{2}$ murni dan $\mathrm{TiO}_{2}$ doping $\mathrm{Cu}$ 
Tahap berikutnya didapatkan lapisan tipis $\mathrm{TiO}_{2}$ : $\mathrm{Cu}$ menggunakan teknik spin coating dengan variasi pemanasan (annealing) $500^{\circ} \mathrm{C}$ dan $600^{\circ} \mathrm{C}$. Sampel tersebut dikarakterisasi menggunakan spektrometer UV-VIS untuk mengetahui besarnya nilai trasmitansi pada panjang gelombang daerah UV-VIS.
3.2 Pembuatan Lapisan Tipis Menggunakan Teknik Spin Coating

Lapisan tipis dari bahan $\mathrm{TiO}_{2}$ dan $\mathrm{TiO}_{2}$ doping $\mathrm{Cu}$ telah dibuat di atas substrat kaca menggunakan teknik spin coating. Lapisan tipis $\mathrm{TiO}_{2}$ doping $\mathrm{Cu}$ dibuat dengan variasi konsentrasi doping $\mathrm{Cu} 1 \%, 2 \%, 3 \%, 4 \%, 5 \%, 6$ $\%, 7 \%, 8 \%, 9 \%$ dan $10 \%$. Lapisan tipis yang dihasilkan ditunjukkan pada Gambar 3 berikut :

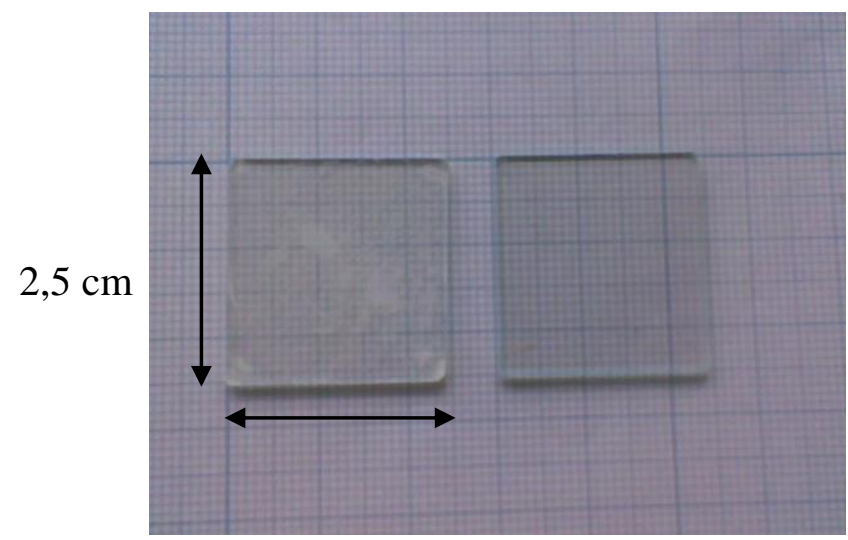

Gambar 3. Lapisan tipis $\mathrm{TiO}_{2}$ doping $\mathrm{Cu}$ dan substrat kaca

3.3 Pengaruh Konsentrasi Doping $\mathrm{Cu}$ pada lapisan Tipis $\mathrm{TiO}_{2}$ terhadap Energi Gap dengan Suhu Annealing $500^{\circ} \mathrm{C}$

Energy gap pada lapisan tipis $\mathrm{TiO}_{2}$ doping $\mathrm{Cu}$ dapat diketahui dengan mengolah data transmitansi yang diperoleh dengan menggunakan spektrometer UV-Vis (UV mini-
1240 Shimadzu). Data yang diperoleh yaitu data transmitansi antara panjang gelombang dari cahaya ultraviolet hingga cahaya tampak (300 $\mathrm{nm}-700 \mathrm{~nm}$ ). Data transmitansi pada lapisan tipis $\mathrm{TiO}_{2}: \mathrm{Cu}$ dengan suhu annealing $500^{\circ} \mathrm{C}$ ditampilkan pada Gambar 2.4 berikut ini.

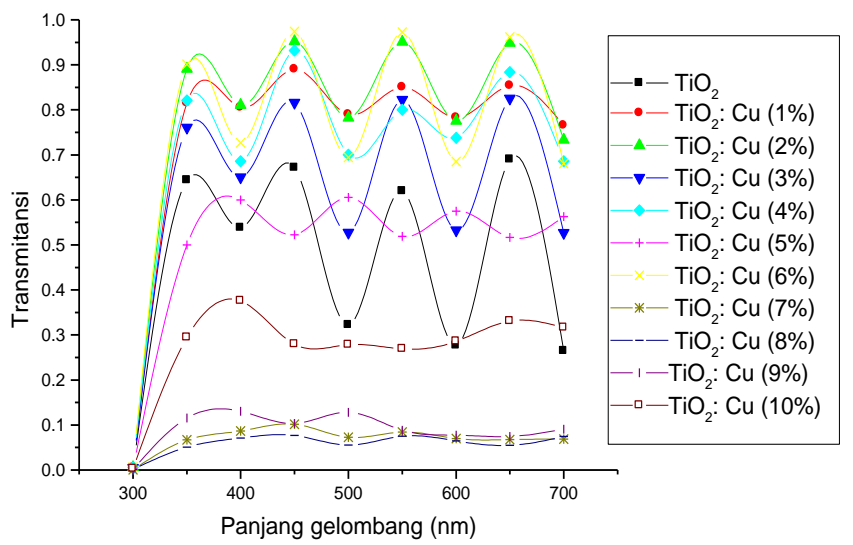

Gambar 4. Transmitansi lapisan tipis $\mathrm{TiO}_{2}$ doping $\mathrm{Cu}$ dengan suhu annealing $500^{\circ} \mathrm{C}$

Pada gambar 4. teramati dengan jelas transmitansi minimum berada pada konsentrasi doping $\mathrm{Cu} 8 \%$. Transmitansi pada panjang gelombang $300 \mathrm{~nm}$ sangat kecil dibandingkan 


\section{Jurnal Pendidikan Fisika dan Keilmuan (JPFK) Vol 3 No 1 Maret 2017, hal 19-27 \\ Avaliable online at : http://e-journal.unipma.ac.id/index.php/JPFK \\ Print ISSN: 2442-8868, Online ISSN: 2442-904x}

400 nm-700 nm. Berdasarkan hukum lambert beer apabila cahaya yang diteruskan pada panjang gelombang $300 \mathrm{~nm}$ bernilai kecil maka cahaya yang diserap besar[Sawitri, 2010]. Transmitansi maksimum pada panjang gelombang 300-700 nm menunjukkan bahwa elektron tidak dapat menyerap energi pada panjang gelombang tersebut, sehingga energi yang diberikan hanya diteruskan saja. Nilai transmitansi minimum pada $300 \mathrm{~nm}$ ini merupakan nilai optimum penyerapan energi oleh elektron sehingga elektron memiliki energi yang cukup untuk melewati energy gap [Romzie, 2008]. Data transmitansi dengan panjang gelombang 300 hingga $700 \mathrm{~nm}$ dapat digunakan untuk menentukan nilai indeks bias dan ketebalan lapisan tipis dengan menggunakan metode Swanepoel [Swanepoel, 1983].

Grafik transmitansi lapisan tipis $\mathrm{TiO}_{2}: \mathrm{Cu}(8 \%)$ dengan suhu annealing $500^{\circ} \mathrm{C}$ ditampilkan pada Gambar 5 berikut ini.

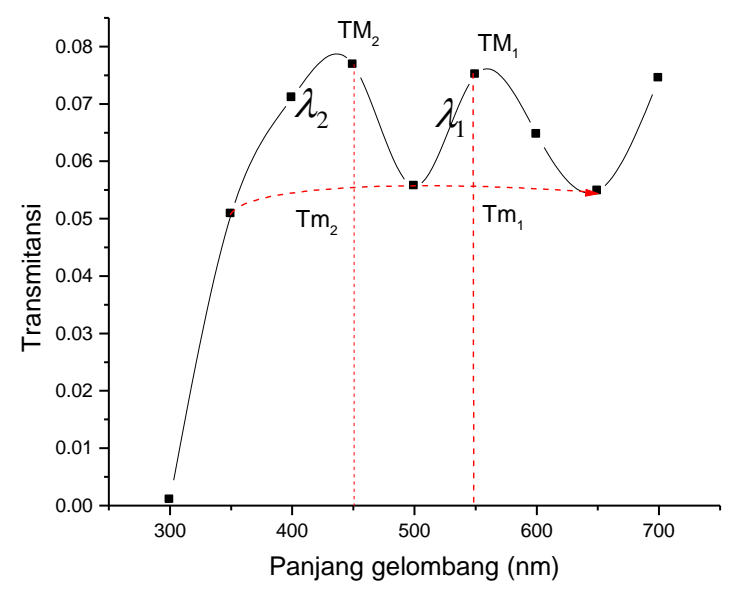

Gambar 5. Transmitansi lapisan tipis $\mathrm{TiO}_{2}: \mathrm{Cu}(8 \%)$ dengan suhu annealing $500^{\circ} \mathrm{C}$

Pembuatan grafik lapisan tipis $\mathrm{TiO}_{2}: \mathrm{Cu}$ dibuat dengan menggunakan software Origin 5.0. Nilai energy gap lapisan tipis $\mathrm{TiO}_{2}$ doping $\mathrm{Cu}$ dengan suhu annealing $500{ }^{\circ} \mathrm{C}$ ditunjukkan pada gambar 6 dan 7 di bawah ini :

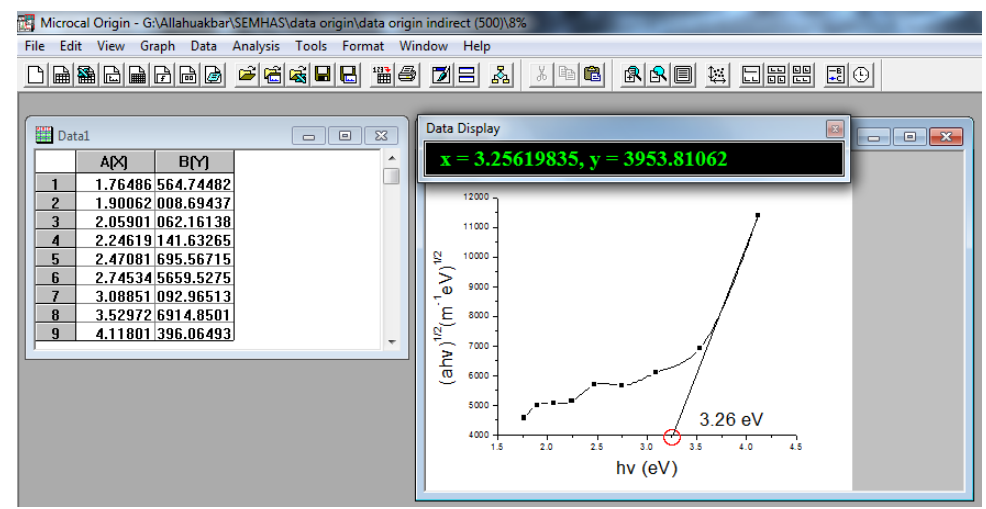

Gambar 6. Direct gap $\mathrm{TiO}_{2}: \mathrm{Cu}(8 \%)$ dengan suhu annealing $500{ }^{\circ} \mathrm{C}$ 
Jurnal Pendidikan Fisika dan Keilmuan (JPFK) Vol 3 No 1 Maret 2017, hal 19-27

Avaliable online at : http://e-journal.unipma.ac.id/index.php/JPFK

Print ISSN: 2442-8868, Online ISSN: 2442-904x

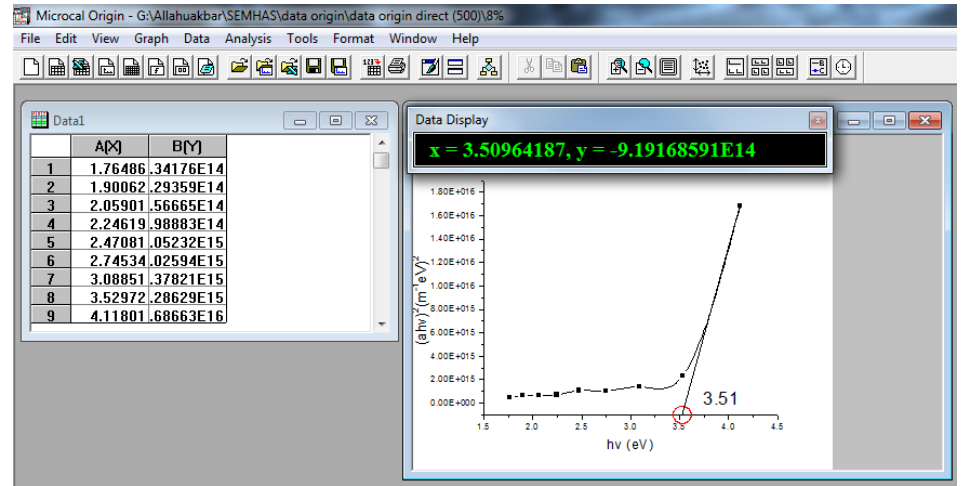

Gambar 7. Indirect gap $\mathrm{TiO}_{2}: \mathrm{Cu}(8 \%)$ dengan suhu annealing $500{ }^{\circ} \mathrm{C}$

Besarnya nilai energy gap $\mathrm{TiO}_{2}$ dan $\mathrm{TiO}_{2}$ : $\mathrm{Cu}$ ditunjukkan pada tabel 2.berikut ini.

Tabel 2. Nilai energy gap $\mathrm{TiO}_{2}: \mathrm{Cu}\left(500^{\circ} \mathrm{C}\right)$

\begin{tabular}{ccc|}
\hline $\begin{array}{c}\text { Konsentrasi } \\
\text { doping }(\%)\end{array}$ & $\begin{array}{c}\text { Direct } \\
\text { gap }(\mathbf{e V})\end{array}$ & $\begin{array}{c}\text { Indirect } \\
\text { Gap }(\mathbf{e V})\end{array}$ \\
\hline 0 & 3.59 & 3,57 \\
1 & 3.57 & 3,57 \\
2 & 3.57 & 3,57 \\
3 & 3.57 & 3,57 \\
4 & 3.57 & 3,57 \\
5 & 3.56 & 3,42 \\
6 & 3.56 & 3,57 \\
7 & 3.53 & 3,37 \\
8 & 3.51 & 3,26 \\
9 & 3.55 & 3,39 \\
10 & 3.57 & 3,43 \\
\hline
\end{tabular}

Berdasarkan data tersebut, terlihat bahwa doping $\mathrm{Cu}$ pada $\mathrm{TiO}_{2}$ cenderung mempersempit energy gap film tipis. Penyempitan energy gap ini disebabkan oleh munculnya level energi baru diantara level valensi dan level konduksi yang dibentuk oleh doping $\mathrm{Cu}[10]$. Pengaruh konsentrasi doping terhadap energy gap dengan suhu annealing $500^{\circ} \mathrm{C}$ disajikan pada Gambar $8 \mathrm{a}$ untuk direct gap dan Gambar 8b untuk indirect gap berikut ini.
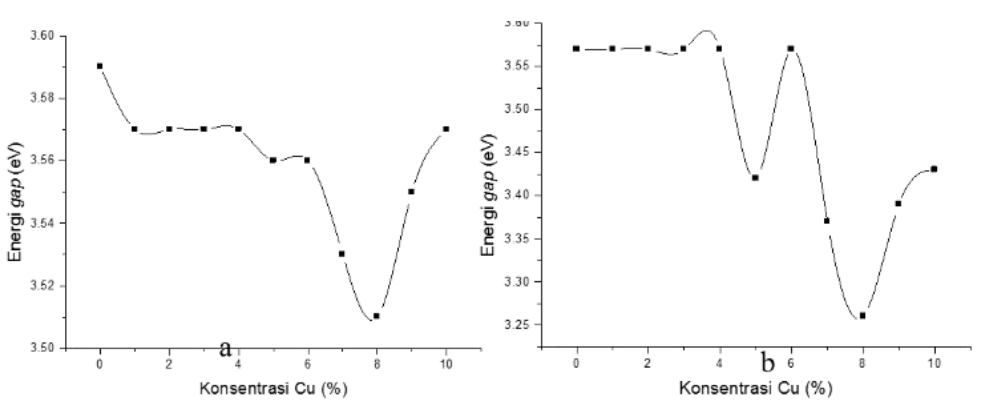

Gambar 8 Pengaruh konsentrasi doping $\mathrm{Cu}$ terhadap energy gap lapisan tipis $\mathrm{TiO}_{2}$ dengan suhu annealing $500^{\circ} \mathrm{C}$, a. direct gap dan b. indirect gap 
Gambar 2.7 menunjukkan bahwa konsentrasi $\mathrm{Cu}$ yang baik untuk mempersempit energy gap lapisan tipis $\mathrm{TiO}_{2}$ : $\mathrm{Cu}$ dengan suhu annealing $500{ }^{\circ} \mathrm{C}$ adalah konsentrasi doping $\mathrm{Cu}$ $8 \%$. Konsentrasi yang kurang atau berlebihan tidak baik untuk bahan semikonduktor $\mathrm{TiO}_{2}$. Pada konsentrasi tertentu energy gap mengalami kenaikan, hal ini dikarenakan kemampuan $\mathrm{Cu}$ tidak dapat mensubstitusi titanium, $\mathrm{Cu}$ hanya berada pada permukaan titanium. Sehingga walaupun $\mathrm{Cu}$ yang didopingkan banyak, $\mathrm{Cu}$ yang mensubstitusi titanium tetap sedikit[Romzie, 2008].

\section{KESIMPULAN}

Berdasarkan pembahasan yang telah di lakukan dapat disimpulkan sebagai berikut hasil karakterisasi sifat optik menggunakan spektrometer UV-Vis menunjukkan bahwa energy gap yang paling sempit pada lapisan tipis $\mathrm{TiO}_{2}$ doping $\mathrm{Cu}$ dengan suhu annealing $500{ }^{\circ} \mathrm{C}$ dapat dicapai pada konsentrasi $\mathrm{Cu}$ sebesar 8 wt.\%. Untuk menyempurnakan penelitian ini maka perlu dilakukan penelitian lebih lanjut tentang karakterisasi sifat listrik lapisan tipis $\mathrm{TiO}_{2}$ doping $\mathrm{Cu}$ yang telah dibuat. Selain itu, penelitian lebih lanjut tentang karakterisasi XRD dan SEM untuk mengetahui struktur dan morfologi lapisan tipis $\mathrm{TiO}_{2}$ doping $\mathrm{Cu}$ yang telah dibuat.

\section{DAFTAR PUSTAKA}

Choi W.Y., Termin A., Hoffmann M.R, (1994). "The Role of Metal Ion Dopants in Quantum-Sized $\quad \mathrm{TiO}_{2}$ : Correlation between Photoreactivity and Charge Carrier Recombination Dynamics", J. Phys Chem, Volume 98. 13669 13679.

Chong W., (2006)"Optical Properties of Amorphous Selenium Films", University of Saskatchewan, Canada, Thesis.

Faith, W,L, Donald B Keyes, Ronald L Clark, (1975). " Industrial Chemical". Wiley, Newyork.

Huriawati, F., Kurniadi, E., \& Irzaman, I. (2016). Pengujian Film Tipis Ba0.5Sr0.5TiO3 (BST) Sebagai Sensor

Cahaya Berbantuan $\begin{array}{r}\text { Rangkaian } \\ \text { Elektronika.JURNAL }\end{array}$ PENDIDIKAN
FISIKA DAN KEILMUAN (JPFK), 2(2),
61-64.

Indah, A. A., (2009).“Distribusi Celah Pita Energi Titania Kotor", Jurnal Nanosains dan Nanoteknologi, Edisi khusus Agustus 2009. ISSN 1979-0880.

Musliahfatun S.,(2010)."Penumbuhan Film Tipis $\mathrm{TiO}_{2}: \mathrm{Nb}$ dengan Metode Spin Coating dan Karakterisasinya", Purwokerto, Skripsi S1 UNSOED.

Nathaniel Coleman Jr. (2015). "Synthesis and Characterization of metal doped titanium dioxide, trasnsition metal phosphides, sulfides and thiophosphates for photocatalysis and energy applications. University of Jowa. Theses and Dissertations.

Prathama R.R.(2010) "Penumbuhan Film Tipis $\mathrm{TiO}_{2}: \mathrm{Fe}$ dengan Metode Spin Coating dan Karakterisasinya", Purwokerto, Skripsi S1 Fisika.

Romzie M., (2008)“Studi Konduktivitas Listrik Kurva I-V dan Celah Energi Fotodioda Berbasis Film Tipis $\mathrm{Ba} 0,75 \mathrm{Sr} 0,25 \mathrm{TiO} 3$ (BST) yang Didadah Galium (BSGT) Menggunakan Metode Chemical Solution Deposition (CSD)", IPB, Bogor, Skripsi S1 Fisika.

Sawitri A.,(2010)"Pengaruh Konsentrasi dan Ketebalan terhadap penyerapan cahaya (Hukum Beer-Lambert)", Jurnal Jurusan Fisika, Fakultas Sains dan Teknologi, Universitas Islam Negeri Sunan Gunung Jati, Bandung.

Slamet R., Marliana E.,(2007).”Pengolahan limbah $\mathrm{Cr}(\mathrm{VI})$ dan Fenol dengan Fotokatalis Serbuk $\mathrm{TiO}_{2}$ dan $\mathrm{CuO} / \mathrm{TiO}_{2}$ ", Reaktor, Vol.11 No.2, Hal: 78-85.

Swanepoel R.,(1983) "Determination of the thickness and optical constants of amorphous silicon", Journal of Physics E: 
Jurnal Pendidikan Fisika dan Keilmuan (JPFK) Vol 3 No 1 Maret 2017, hal 19-27

Avaliable online at : http://e-journal.unipma.ac.id/index.php/JPFK

Print ISSN: 2442-8868, Online ISSN: 2442-904x

Scientific Instruments 16(12), pp. 12141222 ,

Tauc J, Grigorovici R. and Vancu A.,(1966)

Optical Properties and Electronic
Structure of Amorphous Germanium., Phys. Stat. sol. 15, 627. 